\title{
Ecumenism in Poland - movement full of contrasts
}

Since the beginning of Christianity, the consequences of the separations (regarding doctrine and tradition) have been permanent and painful - full of contrasts (conflicts, differences); contrasts that present a certain phenomenon, by showing it in comparison with another but completely different phenomenon. Therefore the article presents a set of selected positive and negative ecumenial experiences. The purpose of such combination of opposites is to emphasize the characteristic features that particular Churches or Christian Communities present, and simultaneously it shows the Christians' responsibility for seeking unity. As John Paul II formulated it, ecumenism is "a movement towards unity". Ecumenism is not merely the "sign of the times", but it is a duty and responsibility in the face of God and His saving plan. It lies with those who through Baptism became Christ's body and His people.

Key words: John Paul II, Roman Catholic Church, Polish Ecumenical Council, dialogue, ecumenism.

\section{Introduction}

In the history of Church, the second millenium of Christianity has been marked with many separations among Christians. However, if we think about the unity of the followers of Christ, we have to go back as far as the beginnings of Christianity, and we will also find it mentioned in different places of the New Testament starting with the High Priest's Prayer, in which Jesus prayed to His Father with the words: "That they may all be one; as thou Father, art in me, and I in thee, that they may 
be in us: that the world may believe that thou didst send me" $(\mathrm{J} 17,21)$. When, after the death and resurrecion of Jesus Christ, in various towns of the ancient world Churches were born, all Christians were aware of the fact that they participated in a work spread all over the globe. Paul the Apostle, in his Epistole to the Ephesians, said: "There is one body, and one Spirit, even as also ye were called in one hope of your calling; One Lord, one faith, one baptism" (Eph 4, 4).

In the year 200, Saint Irenaeus, in his work Against Heresies, stressed that the tradition handed down from the apostles creates the unity among tribes, different cultures, languages and various nations. This teaching and creed "was inherited by the Church scattered all over the world, and it guards it diligently (...)". ${ }^{1}$

Christian faith resulted in creation of specific Churches in various places in the world: in Rome, Antiochia, Alexandria, Germania, Laodycea, Lyon, and people who created those Churches were aware that they belonged to one Church which was present in the whole inhabited world. The Greek word oikumene should be translated: "the whole inhabited world". Therefore, the Church of Christ has, in its essence, been ecumenical since the very beginning because in contrast to earlier religious experiences, which were limited to strengthening the unity of tribes and nations, Christianity has built the experience of unity so far unknown in the history of mankind: the unity with all people.

The problem of unity in Church appeared in the $3^{\text {rd }}$ century and lasted till the $5^{\text {th }}$ century. The first work discussing the problem of the mystery of the Church in a systematic way is St. Cyprian's, the bishop of Carthage, treatise titled On the Unity of Catholic Church written in 251 A.D. The reason for that treatise was the separation among Christians in the Roman Church caused by Novatian. St. Cyprian, sending this treatise to Rome, wanted to put an end to the followers of that sect, advocating a policy under which former idolators could be once again admitted to communion with the real Church. St. Cyprian, "theAfrican Pope" as his nickname was, was on of the first theologians of unity in the Church".

Another painful separation among Christians took place in 1054 . It was the Eastern schizm - split in Christianity into the Eastern and Western Church.

Since the beginning of Christianity, the consequences of the separations (regarding doctrine and tradition) have been permanent and

Antologia Patrystyczna, trans. A. Bober SJ, Kraków 1966, p. 31.

2 J. O. Bragança, Kościót jeden i jedyny. Teologia św. Cypriana z Kartaginy, „Communio” 8 (1988), no 2, p.27-29. 
painful - full of contrasts (conflicts, differences); contrasts that present a certain phenomenon, by showing it in comparison with another, but completely different phenomenon. The purpose of such combination of opposites is to emphasize the characteristic features that particular Churches or Christian Communities present. The breakthrough event in eliminating these contrasts, i.e. destroying the walls separating Christians and opening the way to build a full visible unity among them, was the Second Vatican Council (1963-1965). It opened the Roman Catholic Church onto other Christian denominations, starting from the basic assumption that every separation is not only against the will of Christ but also a threat to the world ${ }^{3}$, and in the final effect it is directed against the Church. Therefore, Christians "united in imitating the martyrs cannot be separated" because "the sin of our separation is very serious" 5 . John Paul II, continuing the ecumenical path of his predecessor, intensified the efforts to restore the full visible unity among Christians in Church, and in this spirit he introduced the Church into the third millenium. He did his best to make the Church more reconciled than separated in the third millenium. John Paul II appealed to all Churches:

"We cannot come before Christ, the Lord of history, as divided as we have unfortunately been in the course of the second millenium. These divisions must give way to rapprochement and harmony; the wounds on the path of Christian unity must be healed". Going beyond our own frailties, we must turn to Him, the one Teacher, sharing in his death so as to purify ourselves from the jealous attachment to feelings and memories, not of the great things God has done for us, but of the human affairs of a past that still weighs heavily on our hearts ${ }^{6}$.

Hence ecumenism is a movement, which in the dialogue full of love and truth, revises the existing divisions and differences all over the world, including Poland, of course.

3 Cf. Dekret o ekumenizmie, in: Sobór Watykański II. Konstytucje. Dekrety. Deklaracje, Poznań 2002, no 1 (next: DE).

4 John Paul II, List apostolski „Tertio millenio adveniente” (10.11..1994), No.1, in: „Ut unum”. Dokumenty Kościoła katolickiego na temat ekumenizmu 1982-1988, ed. S.C. Napiórkowski, K. Lesniewski, J. Lesniewska, Lublin 2000, p. 266-267. Dokumenty Kościoła katolickiego..., p. 311. 


\section{Ecumenical relationships between Roman Catholic Church in Poland and Polish Ecumenical Council}

Ecumenism is a word which describes reality. The word has entered the scene of today's Christianity, also in Poland, and refers to experiences starting at the beginnings of Chruche's activity.

Polish ecumenism has its roots in the Protestant unification movement. By the end of 1942, basing on the experience of the National Department of the World Association for Promoting Friendship among Nations through Churches, the Provisional Ecumenical Council was constituted in Warsaw. The Council was the result of clandestine ecumenical meetings organized for more than two years. At the beginning of its activity, it was more an association of people representing various Churches than an organized forum of Churches. In that time, "Polish Christians' Confession of Faith" (Polish Confession) formulating the dogmatic principles recognized as the common good of all Christians, was developed. It was signed in the Methodist chapel in Warsaw in March 1944 by the clergy of the following Churches: Evangelical Church of Augsburg Confession, Evangelical Reformed, Evangelical Methodistic, Old Catholic Church of the Marialavites and Polish National Catholic Church. The official presentation of Provisional Ecumenical Council took place in Warsaw on $14^{\text {th }}$ October, 1945 . Besides the representatives of the five above mentioned Churches, Polish Baptists and Orthodox also declared their participation in the work of the Council. The meeting started with an ecumenical service. At the plenary session of the Council, the representatives of the above mentioned Churches declared their willingness to belong to the Council on order to deepen their ecumenical commitment. Simultaneously, they decided to promote in their own confessional circles the ecumeniacal spirit of brotherhood and cooperation, according to a saying: "what connects us is of higher quality than that what divides us"?

Twenty years before the Roman Catholic Church got officially engaged in the ecumenical activity, the Polish Ecumenical Council had already functioned. The Council consists of Churches of Protestant and Old Catholic tradition, and the Orthodox Church. Other initiatives than Catholic were and still are accomplished basing on the structure of this Council. The official constitution of the Polish Ecumenical Council took place in Warsaw on $15^{\text {th }}$ November, $1946^{8}$. At the turn of $1950 \mathrm{~s}$ and

\footnotetext{
$7 \quad$ K. Karski,Powstanie i rozwój PolskiejRadyekumenicznej, „Studia i Dokumenty ekumeniczne"12 (1996) No.2, p. 38.

Ibidem. p. 38.
} 
1960s, after Pope John XXIII had announced the idea of convening the general council, an ecumenical opening took place in the Roman Catholic Church. This opening could also be felt in Poland. After the Second Vatican Council, the Roman Catholic Church undertook a number of spiritual, doctrinal and practical ecumenical initiatives. In 1968, the Conference of Polish Episcopate issued a pastoral letter in which Catholics were called to show fraternal respect for the Christian Orthodox, Protestants and members of other Christian Communities. The bishops expressed their desire to overcome mistrust and avert malevolence which would allow to take closer ecclesiastical contacts and establish a fruitful dialogue ${ }^{9}$.

Polish Episcopate Commission for Ecumenism (now Polish Bishops' Council for Ecumenism) faced a very important task - first to make contact, and later start cooperation with Churches associated in Polish Ecumenical Council, as the modern ecumenical movement seeks reconciliation and reconstruction of unity with Churches and not only with individual persons or groups of Christians. On $7^{\text {th }}$ December 1977, a Subcommittee for Doctrinal Dialogue was established. It began its work with discussions with the Churches associated in PEC about the issue of respecting baptism administered in particular Churches, and the mutual recognition of this sacrament. The Roman Catholic Church in Poland and Churches associated in Polish Ecumenical Council signed the declaration about mutual recognition of the sacrament of the holy baptism on $23^{\text {rd }}$ January, 2000. It means that a person's baptism in one of these Churches is respected by the other ones and it does not need to be repeated. Baptism administered in the Roman Catholic Church, and in the following Churches: Evangelical-Reformed, Polish Catholic, Polish Autocephalous Orthodox Church and Old Catholic Church of the Marialavites, is considered as valid. At the end of The Declaration of Churches in Poland at the Beginning of the third Millenium there is an optimistic - ecumenical - accent: Baptism in Christ is a call to the Churches to overcome their divisions and to manifest their unity in a one visible way ${ }^{10}$.

In the practice of Christian Churches, baptism shows how important it is for the unity of Christians. At the same time it is the base for creating Christian community - "ecumenism of communion".

9 List Pasterski Episkopatu „O dążeniu do jedności chrześcijan” (Warszawa, 23.10.1968), in: „Ut unum”. Dokumenty Kościoła katolickiego na temat ekumenizmu 1982-1998, ed. S. C. Napiórkowski, Lublin 1998, p. 209-214.

10 Sakrament chrztu znakiem jedności. Deklaracja Kościołów w Polsce na progu trzeciego Tysiaclecia, in: Encyklopedia ekumenizmu w Polsce (1964-2014), ed. J. Budniak, Z. Glaeser, T. Kałużny, Z. J. Kijas, Kraków 2016, p. 514-515. 
The other issue the Subcommittee for Doctrinal Dialogue dealt with was the question of marriages of different ecclesiastical affiliations. A pastoral instruction, developed by the Subcommittee and discussed with the representatives of PEC, was aproved by the Conference of Polish Episcopate and handed on to the bishops to be put into practice in the dioceses.

One of the important areas in the ecumenical cooperation in Poland has been, since 1994, the engagement of the Churches in the new, joint translation of the Scriptures. On $17^{\text {th }}$ March, 2018, Warsaw was the place where the Ecumenical Bible was launched. It is a new translation of the Holy Scripture of the Old Testament and New Testament (ecumenical translation from native languages) prepared by the International Translation Team of the Bible Society in Poland. The Synod of the Evangelical Church of Augsburg Confession, during the debates on $4^{\text {th }}$ April, 2018, adopted a resolution about the use of the Ecumenical Bible during liturgy. That way the Evangelical Church of Augsburg Confession in Poland has become the first Church associated in the Polish Ecumenical Council to use this Bible in liturgy and the texts from the Bible will be used in meditations during ecumenical services.

In the process of making the visual unity of Christians real - according to the documents of Christian Churches and interfaith dialogues - spiritual ecumenism takes a special place. Its essence is the inner transformation which is the result of the Holy Spirit's action and shows the way how to live according to the Gospel in the spirit of following Christ. Therefore in the centre of the pursuit of unity is the prayer, whose source is the desire of Jesus Himself "that they may all be one [...], that the world may believe" ( $\mathrm{J} 17,21)$. "This conversion of the heart and the sanctity of life including public and private prayers for the unity of Christians - as it was underlined in the Council's Decree on Ecumenism - should be considered as the soul of the whole ecumenical movement" (DE 8). One of the oldest and most developed forms of spiritual ecumenism in Poland is the Week of Prayers for Christian Unity, traditionally celebrated from $18^{\text {th }}$ to $25^{\text {th }}$ January every year.

Thinking about ecumenism in Poland, we come to the reflection that the unification movement in our country is one which runs on two rails. It is a movement full of contrasts, similar to our Polish reality, also full of contrasts. This twofold movement consists of: The beginnings of Polish ecumenical movement.

It started in the year 1925 (Bishop Juliusz Bursche, Fr. Prof. Dr Jan Szeruda, Fr. Zygmunt Michelis), was continued during World War II and in the first postwar years. People of different denominations were 
truly united by their shared misery. It is no wonder, though, that after the war they kept to what they had vowed to each other in concentration camps, bunkers or the underground. It was how the Christian Ecumenical Council in Warsaw started. Later it was changed into the Polish Ecumenical Council.

Contemporary Polish ecumenical movement. This movement began when the Roman Catholic Church started to cooperate with the Polish Ecumenical Council after Vatican II (1962-1965). As Karl Rahner said "new seed germs" presented themselves after Vatican II. Soon after the Council was finished, the Polish translation of Council's documents appeared. Looking at the development of ecumenical relations between Churches in Poland, it can be said that the words spoken by the Melechite patriarch Maximos IV in the Council's aula, are true: "Ecumenism is a door opened for us by the Holy Spirit Himself, a door which nobody can close any more" 11.

After the collapse of the totalitarian system (after 1989), more Churches joined the ecumenical movement - Seventh-day Adventists, Christ's Congregations and Pentacostal. However, the cooperation between the Churches joined in the Polish Ecumenical Council and the Roman Catholic Church was not so easy. Not always were the Churches to be blamed. There was another "partner" that always tried to stand between them. This "partner" were the state authorities. It must be said that the then authorities did their best to prevent the CatholicProtestant-Orthodox-Old Catholic meetings. They did everything to prevent the Protestant Church from selling their church buildings to the Catholic Church. In consequence, particularly in the Mazury Region, Catholics illegally occupied the unused Protestsnt churches, but unfortunately those in use, too. It led to great controversies in the relations between churches. Also in the postwar times in Mazury, the communist authorities played a big role in stiring up arguments between Lutherans and Methodists.

The first contacts between the Protestant Churches and the Roman Catholic Church were established by the already mentioned bishop Zygmunt Michelis in 1959. The first ecumenical service in history took place in the Warsaw Roman Catholic St. Marcin church on $10^{\text {th }}$ January, 1962. Bishop Zygmunt Michelis was preaching. Similar services took place in Cieszyn Silesia and the moderator of those meetings was - from the Catholic side - Bishop Herbert Bednorz, and from the Protestant - Rev. Jan Gross, the precursor of the ecumenical movement in Silesia. At first, both met on a private ground. In that region, the

$11 \quad$ Cf. A. Skowronek, Teologiczne zbliżenia, Warszawa 1993, p. 137. 
first ecumenical service took place in the Catholic church in Pruchna in January 1969. In the 1970s, ecumenical services and concerts were organized both in Catholic an Protestant churches. Those were the beginnings of ecumenicsm on a large scale. Two more true ecumenists joined the group - Archbishop Alfons Nossol and Fr. Arkadiusz Miś from Drogomyśl.

As it was already said, our ecumenism moves somehow on two rails of one track. One rail is the one which has been used for many years by the Churches associated in the Polish Ecumenical Council, gathering three Christian traditions: Protestant, Orthodox and Old Catholic. The second, younger rail put in the 1960s and 1970s, is the Roman Catholic rail. Both rails run alongside, sometimes they are close and sometimes the are more distant. But they should not be too far away from each other and they should not drift apart if they want to fulfill together the prayer of our Lord, particularly the words: "Holy Father, keep them in thy name which thou hast given me, that they may be one, even as we are" (J 17, 11).

\section{Positive and negative selected ecumenical experiences}

In the ecumenical activities you can encounter positive and negative experiences which arise from historical separations, conflicts and differences. Among the ecumenical experiences a few selected examples - positive and negative - can be presented.

The Roman Catholic Church and the Orthodox Church have had animated talks for many years. There are good relationships between Catholics and the ecumenical patriarch of Constantinople, Bartholomew, who said that the unification of the two branches of Christianity was inevitable. The situation looks different in the bilateral dialogue with Moscow Orthodox. The Wallachian Metropolitan Bishop, Hilarion (Ałfiejew), responsible for the administration of the Moscow Patriarchate and foreign affairs in the Russian Orthodox Church, takes the view that the Orthodox Church and the Roman Catholic Church will never get united because of many conflicts and misunderstandings that have accumulated in the thousand-year history of their separation. The foundations of faith are identical and the Credos are almost identical, but the Catholics have a different understanding of the origin of the Holy Spirit than the Orthodox (dispute about filioque). The Orthodox hierarch stressed that there were also differences about the diptychs of canonized persons. He claimed that some saints respected by the Catholic Church were seen as heretics and persecutors of the 
Orthodox by the Russian Orthodox Church. As an example he gave Cardinal Stepinac. In his speech, he said that:

Catholics are talking about the possible canonization of Cardinal Stepinac who was Croatian, and he is already treated as if he were a saint, but for example in the opinion of the Serbian Orthodox Church the Cardinal was directly involved in the extermination of Serbs in the Second World War ${ }^{12}$.

There are other disputable issues which show that the unification of Churches is not a clear perspective for the future. The Orthodox remember well the numerous attempts to impose a union upon them Ecumenism during the crusades and the contemporary antiorthodox activities of the Greek Catholic Church (Uniate) in Ukraine.

On $23^{\text {rd }}$ January, 2000 in Warsaw Lutheran Holy Trinity cathedral, the Churches of the Polish Ecumenical Council, except the Baptist Church (dogmatic reasons), and the Roman Catholic Church signed a common declaration about their mutual recognition of the Sacrament of Holy Baptism.

After the introduction of religion lessons at schools (1990/1991), on the one hand the Churches got closer with each other because they organized many events together, especially in the Christmas time, or they organized biblical competitions. But on the other hand, there occurred misunderstandings among the children of different denominations caused by lack of tolerance, as the children had been brought up in the environment filled with hatred for the other religion. In one of the secondary schools in Cieszyn Silesia in the 1960s, there was a teacher who used to put the letters "P" (Protestant) and "C" (Catholic) next to his pupils' names in the class register forgetting that school is a place free of religious prejudices.

Within theological universities and faculties in Poland, separate departments and sections of ecumenical theology were founded. They initiated the foundation of several dynamically operating Ecumenical Institutes. The first of them was established at the Theological Faculty of the Lublin Catholic University that celebrates its $100^{\text {th }}$ anniversary of existence in 2018. These examples should be seen as another positive ecumenical experience in our country.

In 1994, the Opole University with a Theological Faculty was established. Since the very beginning of this University, there has been a Faculty of Ecumenism and Comparative Theology.

12 (n.a.), Nie będzie zjednoczenia prawosławnych i katolików, http://www.ekumenizm.pl/koscioly/wschodnie/nie-bedzie-zjednoczenia-prawoslawnych-i-katolikow/ (07.05.2018). 
The academic community in Cieszyn is also worth mentioning as at the Branch of Pedagogical-Artistic Faculty of the Silesian University, in the academic year 1998/1999, there was opened a department of Religious Education which took on a new dimension, i.e ecumenical. In the building of Cieszyn Alma Mater, an ecumenical chapel was established and consecrated on $12^{\text {th }}$ May 1998. In the premises of the university, members of the Polish Region of International Ecumenical Fellowship organized an International Ecumenical Congress (21-28 August, 1995) for the first time in Poland. The Congress attracted more than three hundred representatives of various Churches from almost all over the world. The leading subject of the meeting was: Renew us through prayer and work ${ }^{13}$.

Following the example of the World Day of Prayer for Peace that was organized for the first time on John Paul's II initiative in Assisi in 1986, where Christians from different Churches and Ecclesial Communities prayed for peace in the world, in Poland such initiative was also taken. Among others, there was held an international ecumenical service for peace in St. John the Baptist church in Brenna, in Cieszyn Silesia on $18^{\text {th }}$ March, 2002. The service gathered clergy from five Christian Churches in Poland and Czech Republic ${ }^{14}$.

Polish President, Bronisław Komorowski, appreciating the role and the significance of ecumenical dialogue in Cieszyn Silesia, came to Cieszyn to participate in the ecumenical prayer for peace in the world on $1^{\text {st }}$ September, 2011. There also participated Catholic and Lutheran bishops, as well as many faithful of both religions. Referring to the geographical position of Cieszyn, President Komorowski said that: "a voice from here, form the border of nations, languages, cultures and religions proves that being different does not mean misfortune but beauty and wealth of Poland and all world's nations"15.

Another positive aspect of Polish ecumenism is the ecumenical translation of New Testament and Psalms published in autumn 2001. The translation was accomplished by theologists of different Christian denominations. The whole Bible, the Old and New Testaments, as it was mentioned before, was published in 2018.

Rev. Jan Gross, the ex-president of the Silesian Branch of Polish Ecumenical Council, wrote in his diaries:

$13 \quad$ Cf. J.Budniak, Ekumenizmjutrana przykładzie Śląska Cieszyńskiego, Katowice 2002, p. 162-173.

14 See Brenna jak Asyż, „Głos Ziemi Cieszyńskiej” Cieszyn, 22.03.2002, p. 1-2.

15 J. Budniak, Wkład społeczności lokalnej $w$ proces pojednania chrześcijan, in: Człowiek dialogu, ed. Z Glaeser, Opole 2012, p. 617. 
When I was a child, at school I often heard my Catholic friends say that entering a Protestant church is for them such a great sin that immediately they have to confess what they had done. When I started my work as priest in Szczytno, one day I was showing the teachers around our Protestant church. When I pointed to the statue of Our Lady with Little Jesus in the main altar, the Catholic teachers told me, that it was really strange because they had always been told that a picture of Our Lady was buried under he threshold of every Protestant church, and everyone who went through the threshold trampled on Her. And here in your church is a statue of Our Lady! ${ }^{16}$.

These examples show the lack of ecumenical knowledge. Nowa- Ecumenism days you do not hear such statements any more. Undoubtedly, the ecumenical education, ecumenical documents and the dialogues have had a great influence on the improvement of the situation.

Not once had John Paul II entered a Protestant church. The best example is his visit in Skoczów on $22^{\text {nd }}$ May, 1995. After the canonization of St. Jan Sarkander, the Pope participated in an ecumenical prayer in the Holy Trinity Evangelical Church of Augsburg Confession. In his speech, John Paul II stressed the importance of the ecumenical dialogue in the Bielsko-Żywiec Diocese. He said:

[...], Cieszyn Silesia is well known in Poland as a place of particular ecumenical testimony. For a long time it has been a region of harmonious coexistence of the faithful from the Catholic Church and Evangelical Church of Augsburg Confession, and an intensive ecumenical dialogue. The dialogue is conducted with a deep conviction that we have so much in common, and what joins us is the common faith in Christ and our homeland ${ }^{17}$.

Further example of positive ecumenical experience is the fact that after 55 years, the Roman Catholic Church represented by Archbishop Damian Zimoń from Katowice, returned the Protestant Martin Luther church in Siemianowice (Laurahütte), built by the Protestants in 1895 and confiscated with the help of the authorities by the Nuns of Visitation who arrived from Vilnus in 1945. This is undoubtedly an important experience in our Polish reality.

There are also some negative experiences. During the Parliament elections in 1997, the party Liga Polskich Rodzin (Ligue of Polish Families) hung calumnious posters about Protestant candidates (Prof. Jerzy Buzek and the Senate Deputy Speaker Marcin Tyrna). The posters

16 J. Gross, Doświadczenia ekumeniczne w Polsce, „Przegląd Ewangelicki” 2003, nr 4, p. 31-32.

17 J. Budniak, Wkład społeczności lokalnej ..., p. 784. 
called on the electorate to boycott those candidates to the Parliament ("The Protestants disappointed us, the communists, too! Look for Catholic candidates on the lists").

In a village run for 12 years by a borough leader who was a Protestant lady, two Catholic priests tried actively to persuade the Catholics that she should not be elected again. When she finally was elected, there were people who managed to lead to the re-election in a part of the borough. In the end effect she received almost 400 votes more than the Catholic candidate. And who re-elected her? Mostly Catholics, because there are only about 70 Protestant inhabitants there. This experience has negative overtones as far as the priests are concerned, but very positive as far as the Catholic faithful are concerned. Because of that, that village did not have the traditional ecumenical harvest festival which is organized in many other Silesian villages every year.

Catholics, Protestants and Christians of other confessions live next to each other as neighbours, meet at work and learn how to live among people of different religions. We should constantly develop in our minds the things that we share in our faith and become conscious of them. We should also seek for unity in spite of the differences that are still present between us. Baptism and Eucharist are the two sacraments accepted by all Christians. As to Baptism there is basic agreement of all Churches. Baptism administered in one Church is accepted in others. There is a lack of similar agreement concerning Eucharist. The fact that Baptism is accepted does not mean that we are allowed to share in one Eucharist. Despite the Christians' longing, they still cannot be united around one altar to consume the same eucharistic bread and drink from the one chalice. This situation is against the will of Jesus who prayed during the Last Supper , "that they may all be one". Eucharist is the sacrament of communion, which means the unity of man not only with the Lord, but also unity of the people with one another. This context highlights the drama of separation best. Christians cannot be indifferent to it.

\section{Conclusion}

After the presentation of the few positive and negative ecumenical aspects, it might be easier to understand that ecumenism in Poland is "a movement full of contrasts, similar to our Polish reality, also full of contrasts". All Christians are responsible for seeking unity, and the prospect that no ecumenical effort is in wain should encourage us. Each good initiative is worth undertaking and makes sense. Unity 
is not the goal alone. Ecumenism is, as John Paul II formulated it: "a movement towards unity"18, and:

those belong to it who invoke the Triune God and confess Jesus as Lord and Saviour, doing this not merely as individuals but also as corporate bodies. For almost everyone regards the body in which he has heard the Gospel as his Church and indeed, God's Church. All however, though in different ways, long for the one visible Church of God, a Church truly universal and forth into the world that the world may be converted to the Gospel and so be saved, to the glory of God (cf. DE 1).

The ecumenical movement is an irreversible process both on the spiritual level and in everyday practice. Ecumenism is not merely the "sign of the times", but it is a duty and responsibility in the face of God and His saving plan. It lies with those who through Baptism became Christ's body and his people. At the same time, the pursuit for reconciliation should be the inner voice of Christian conscience enlightened by faith and guided by love.

\section{EKUMENIZM W POLSCE - RUCH PEŁEN KONTRASTÓW}

Skutki podziałów (dotyczących doktryny i tradycji) od początku chrześcijaństwa są trwałe i bolesne, czyli pełne kontrastów (konfliktów, różnic). Kontrasty, polegające na przedstawieniu pewnego zjawiska, poprzez ukazanie na tle lub obok, zjawiska, zupełnie odmiennego. Stąd w artykule zostały zaprezentowane wybrane pozytywne i negatywne doświadczenia ekumeniczne. Takie zestawienie przeciwieństw służy uwydatnieniu cech charakterystycznych, które prezentują poszczególne Kościoły, czy Wspólnoty chrześcijańskie, a jednocześnie wskazuje na obowiązek dążenia do jedności, który ciąży na wszystkich chrześcijanach. Każda dobra inicjatywa ma swój sens. Jak sformułował Jan Paweł II, ,ekumenizm jest ruchem ku jedności". Ekumenizm bowiem to już nie tylko "znak czasu", ale to obowiązek i odpowiedzialność wobec Boga i Jego zbawczego zamysłu, spoczywająca na tych, którzy przez chrzest stali się Ciałem Chrystusa i nowym Jego ludem.

Słowa kluczowe: Jan Paweł II, Kościół rzymskokatolicki, Polska Rada Ekumeniczna, dialog, ekumenizm.

18 John Paul II, Wiara przeniknięta pragnieniem jedności chrześcijan (catechesis from 26.06.1985, in: https//www.apostol.pl/janpawelii/katechezy/bog-ojciec/ wiara-przeniknieta-pragnieniem-jednosci-chrzescijan (03.05.2018). 


\section{Bibliography:}

1. Antologia Patrystyczna, trans. A. Bober SJ, Kraków 1966.

2. Bragança J.O., Kościót jeden i jedyny. Teologia św. Cypriana z Kartaginy, "Communio" 8 (1988), no 2.

3. Brenna jak Asyż, „Głos Ziemi Cieszyńskiej” Cieszyn, 22.03.2002, p. 1-2.

4. Budniak J., Ekumenizm jutra na przykładzie Śląska Cieszyńskiego, Katowice 2002.

5. Budniak J., Wkład społeczności lokalnej w proces pojednania chrześcijan, in: Człowiek dialogu, ed. Z Glaeser, Opole 2012, p. 617.

6. Dekret o ekumenizmie, in: Sobór Watykański II. Konstytucje. Dekrety. Deklaracje, Poznań 2002.

7. Gross J., Doświadczenia ekumeniczne w Polsce, „Przegląd Ewangelicki” 2003, nr 4, p. 31-37.

8. John Paul II, List apostolski „Orientale lumen” (2.05.1995), in: „Ut unum”. Dokumenty Kościoła katolickiego na temat ekumenizmu 1982-1988, ed. S.C. Napiórkowski, K. Lesniewski, J. Lesniewska, Lublin 2000.

9. John Paul II, List apostolski ,Tertio millenio adveniente” (10.11..1994), in: „Ut unum”. Dokumenty Kościoła katolickiego...

10. John Paul II, Wiara przeniknięta pragnieniem jedności chrześcijan (catechesis from 26.06.1985, in:https//www.apostol.pl/janpawelii/katechezy/bogojciec/wiara-przeniknieta-pragnieniem-jednosci-chrzescijan (03.05.2018).

11. Karski K., Powstanie i rozwój Polskiej Rady ekumenicznej, „Studia i Dokumenty ekumeniczne"12 (1996), No.2.

12. List Pasterski Episkopatu „O dążeniu do jedności chrześcijan” (Warszawa, 23.10.1968), in: „Ut unum”. Dokumenty Kościoła katolickiego na temat ekumenizmu 1982-1998, ed. S.C. Napiórkowski, Lublin 1998.

13. n.a., Nie będzie zjednoczenia prawosławnych i katolików, http://www.ekumenizm. pl/koscioly/wschodnie/nie-bedzie-zjednoczenia-prawoslawnychi-katolikow/ (07.05.2018).

14. Sakrament chrztu znakiem jedności. Deklaracja Kościołów w Polsce na progu trzeciego Tysiaclecia, in: Encyklopedia ekumenizmu w Polsce (19642014), ed. J. Budniak, Z. Glaeser, T. Kałużny, Z.J. Kijas, Kraków 2016.

15. Skowronek A., Teologiczne zbliżenia, Warszawa 1993. 